\title{
Effect of Microstructural Changes during Annealing on Thermoelectromotive Force and Resistivity of Electrodeposited $\mathrm{Ni}_{85.8} \mathrm{Fe}_{10.6} \mathrm{~W}_{1.4} \mathrm{Cu}_{2.2}$ Alloy
}

\author{
M. Spasojević, ${ }^{1}$ A. Maričić, ${ }^{1}$ Z. Vuković, ${ }^{1}$ S. Đukić, ${ }^{1}$ L. Ribić-Zelenović, ${ }^{1}$ and M. Spasojevićc ${ }^{2}$ \\ ${ }^{1}$ Joint Laboratory for Advanced Materials of SASA, Section for Amorphous Systems, Faculty of Technical Sciences, Čačak, \\ University of Kragujevac, Čačak, Serbia \\ ${ }^{2}$ Faculty of Chemistry, University of Belgrade, Belgrade, Serbia
}

Correspondence should be addressed to M. Spasojević; ljiljana.spasojevic51@yahoo.com

Received 13 December 2016; Revised 31 January 2017; Accepted 8 February 2017; Published 31 May 2017

Academic Editor: Mohamed Bououdina

Copyright (C) 2017 M. Spasojević et al. This is an open access article distributed under the Creative Commons Attribution License, which permits unrestricted use, distribution, and reproduction in any medium, provided the original work is properly cited.

\begin{abstract}
$\mathrm{Ni}_{85.8} \mathrm{Fe}_{10.6} \mathrm{~W}_{1.4} \mathrm{Cu}_{2.2}$ alloy powder containing nanocrystals of an FCC-structured solid solution of iron, tungsten, and copper in nickel embedded in an amorphous matrix was electrodeposited from an ammonia citrate solution. The alloy exhibits thermal stability in the temperature range between $25^{\circ} \mathrm{C}$ and $150^{\circ} \mathrm{C}$. Over the range $150-360^{\circ} \mathrm{C}$, the alloy undergoes intense structural relaxation which considerably increases the electron density of states and, hence, its electrical conductivity. Less intense structural relaxation takes place at temperatures between $360^{\circ} \mathrm{C}$ and $420^{\circ} \mathrm{C}$. In the temperature range of $420^{\circ} \mathrm{C}$ to $460^{\circ} \mathrm{C}$, relatively more intense changes in the electron density of states at the Fermi level occur, as induced by the structural relaxation resulting from the stabilization of larger less mobile tungsten atoms and copper atoms. The large decrease in electrical resistivity and the high increase in the electron density of states at the Fermi level in the temperature range $460-520^{\circ} \mathrm{C}$ are due to amorphous matrix crystallization and FCC-phase crystal grain growth.
\end{abstract}

\section{Introduction}

Nowadays, nanostructured materials are extensively used in many technologies due to their specific chemical and physical properties [1-4]. Nickel/iron alloys have good mechanical, electrical, and magnetic properties and a high catalytic activity for some electrochemical reactions [57]. Alloying these alloys with small quantities of tungsten improves their thermal stability, wear resistance, corrosion resistance, microhardness, and high-temperature oxidation [8-17]. NiFeW alloys may exhibit the key properties of NiW and FeW alloys while eliminating the unwanted properties of the two-component alloys. They are widely used in industries, mainly as inductor cores for electromagnets [18-20], magnetic devices [21], microwave noise filters [22], magnetic recording heads [23], and tunable noise suppressors [24]. They are also used as cathodes for the electrochemical production of hydrogen. The metallurgical fabrication of these nanostructured alloys is expensive due to tungsten's high melting point. Therefore, other procedures for their production have been developed, such as mechanical alloying, sputtering, or electrolytic deposition from water baths [8-15, 25-27].

Nanostructured coatings and powders of nickel/iron/ tungsten alloys can be obtained by electrolysis from environmentally friendly citrate ammonia solutions [8-11, 16]. Electrolysis can produce alloys that differ in microstructure and, hence, in electrical, magnetic, and mechanical properties, thermal stability, and corrosion resistance from those of the same chemical composition prepared by metallurgy routes. The properties of electrochemically deposited alloys depend on the kinetic and operational parameters governing electrolysis $[8-15,28,29]$.

Nanostructured alloys are in a metastable state. Annealing at high temperatures causes changes in their structure. Structural relaxation takes place at low temperatures, whereas crystallization occurs at high temperatures. Structural changes affect mechanical, electrical, and magnetic 
properties, catalytic activity, thermal stability, and corrosion resistance $[8-15,28,30]$. Structural changes in nanostructured alloys also lead to changes in the value of the thermoelectromotive force of the nanostructured alloy-crystal alloy (metal) thermocouple [31-34].

Many products made of nickel/iron/tungsten alloys, which are widely applied in industry, agriculture, and medicine, can be obtained in desired shapes and sizes by sintering the powders of these alloys. This is a simple and lowcost procedure which requires a minimum investment.

Nanostructured nickel/iron/tungsten alloy powders having a suitable particle size cannot be deposited from an ammonia citrate bath at high current efficiencies. The codeposition of nickel, iron, tungsten, and small amounts of copper can result in the production of nickel/iron/tungsten/ copper alloy powders with a desired particle size and good electrical and magnetic properties at relatively high current efficiencies from environmentally friendly alkaline citrate ammonia solutions $[35,36]$.

The objective of this study was to examine the effect of structural changes during annealing on the electrical resistivity and thermoelectromotive force of a thermocouple made of electrodeposited nanostructured $\mathrm{Ni}_{85.8} \mathrm{Fe}_{10.6} \mathrm{~W}_{1.4} \mathrm{Cu}_{2.2}$ alloy and copper and to use the experimental results to establish correlations between structural changes, electrical properties, and thermoelectromotive force.

\section{Experimental}

Nickel/iron/tungsten/copper alloy powder was electrodeposited on a titanium cathode from the solution containing $0.2 \mathrm{~mol} \mathrm{dm}^{-3} \mathrm{NiSO}_{4}, 0.02 \mathrm{~mol} \mathrm{dm}^{-3} \mathrm{FeSO}_{4}, 0.004 \mathrm{~mol} \mathrm{dm}^{-3}$ $\mathrm{Na}_{2} \mathrm{WO}_{4}, 0.005 \mathrm{~mol} \mathrm{dm}^{-3} \mathrm{CuSO}_{4}, 0.24 \mathrm{~mol} \mathrm{dm}^{-3} \mathrm{Na}_{3} \mathrm{C}_{6} \mathrm{H}_{5}$ $\mathrm{O}_{7}, 0.8 \mathrm{~mol} \mathrm{dm}^{-3} \mathrm{NH}_{4} \mathrm{Cl}$, and $0.3 \mathrm{~mol} \mathrm{dm}^{-3} \mathrm{Na}_{2} \mathrm{SO}_{4}$. The solution temperature during the electrolysis was $60 \pm 0.5^{\circ} \mathrm{C}$, and $\mathrm{pH}$ was equal to $9.2 \pm 0.2$. The $\mathrm{pH}$ of the solution was adjusted by the addition of $0.6 \mathrm{~mol} \mathrm{dm}^{-3} \mathrm{NH}_{4} \mathrm{OH}$ (during electrolysis). The solution was prepared using p.a. chemicals (Merck) and triple distilled water. During the electrolysis, a $2 \mathrm{dm}^{3}$ standard electrochemical glass cell was used. The anodes were two platinum plates of $12.0 \mathrm{~cm}^{2}$ surface area. A titanium cathode of $4.0 \mathrm{~cm}^{2}$ surface area and $0.3 \mathrm{~cm}$ thickness was positioned in parallel between the anodes. The cell was in a thermostat. The powder was electrodeposited galvanostatically at a current density of $j=450 \mathrm{~mA} \mathrm{~cm}$. The standard electrical circuit comprising a programmer (Universal Programmer, Model 173), a potentiostat (Potentiostat/Galvanostat Model 173), and a voltmeter (Pro's Kit 03-9303C) were employed during the electrolysis. After the electrolysis, the resulting powder was washed three times with distilled water and, then, with a $0.1 \mathrm{wt} . \%$ benzoic acid solution to prevent oxidation. Thereafter, it was dried at $105^{\circ} \mathrm{C}$. The size of powder particles was determined by a Leica Q500MC automatic device for microstructural analysis.

A PEKTAR-A.A.200-VARIAN atomic absorber was used to determine the chemical composition of the powder.

Scanning electron microscopy (SEM) analysis was performed on a JEOL-JSM 5300. X-ray diffraction (XRD) was recorded on a Philips PW 1710 diffractometer using $\mathrm{CuK}_{\alpha}$ radiation $(\lambda=0.154 \mathrm{~nm})$ and a graphite monochromator. XRD data were collected with a step mode of $0.03^{\circ}$ and a collection time of $1.5 \mathrm{~s} \mathrm{step}^{-1}$. Nanocrystallite sizes (D) were determined from the full width at half maximum $(\beta)$ by Scherrer's formula: $D=0.94 \lambda /(\beta \cos \theta)$. The microstrain $(\varepsilon)$ was calculated using the relation: $\beta=\lambda /(D \cos \theta)-\varepsilon \operatorname{tg} \theta$. Minimum density of chaotically distributed dislocations $(\delta)$ was calculated from values of mean nanocrystallite size, $\delta=$ $D^{-2}$

A $40 \mathrm{~mm} \times 1.2 \mathrm{~mm} \times 0.5 \mathrm{~mm}$ sample obtained by pressing the powder at $500 \mathrm{MPa}$ was examined for electrical properties. Electrical resistivity was measured by the fourpoint method in the temperature range of $25^{\circ} \mathrm{C}$ to $600^{\circ} \mathrm{C}$. Measurements were performed under argon atmosphere. Thermoelectromotive force (TEMF) was measured using the nanostructured $\mathrm{Ni}_{85.8} \mathrm{Fe}_{10.6} \mathrm{~W}_{1.4} \mathrm{Cu}_{2.2}$ alloy- $\mathrm{Cu}$ thermocouple, obtained by the mechanical coupling of the pressed powder sample and copper wire. The $\mathrm{Ni}_{85.8} \mathrm{Fe}_{10.6} \mathrm{~W}_{1.4} \mathrm{Cu}_{2.2^{-}}$ $\mathrm{Cu}$ couple was placed into a specially designed furnace, while the other end of the sample was submerged into a mixture of water and ice. The TEMF produced by the thermocouple during the heating process was measured by a voltmeter having a sensitivity of $10^{-5} \mathrm{~V}$.

\section{Results and Discussion}

Nickel/iron/tungsten/copper alloy powder was deposited from an ammonia citrate bath at a current density of $450 \mathrm{~mA} \mathrm{~cm}^{-2}$ on a titanium cathode. The chemical composition of the deposit was determined by atomic absorption. Six different samples electrodeposited under the same conditions were analyzed. The results differed by less than $0.5 \mathrm{wt} . \%$. The average composition of the alloy was 85.8 wt.\% Ni, 10.6 wt.\% Fe, 1.4 wt.\% W, and 2.2 wt.\% $\mathrm{Cu}\left(\mathrm{Ni}_{85.8} \mathrm{Fe}_{10.6} \mathrm{~W}_{1.4} \mathrm{Cu}_{2.2}\right)$.

SEM micrographs of $\mathrm{Ni}_{85.8} \mathrm{Fe}_{10.6} \mathrm{~W}_{1.4} \mathrm{Cu}_{2.2}$ alloy powder are presented in Figures 1(a), 1(b), and 1(c).

Particle size ranges from 10 to $200 \mu \mathrm{m}$. The particles are dendritic in shape and have branches, secondary branches, and higher-order branches. The high density of branches indicates a rapid nucleation during alloy electrodeposition at a current density of $450 \mathrm{~mA} \mathrm{~cm}^{-2}$ in the presence of small amounts of $\mathrm{Cu}^{2+}$ ions. The polarization curves and the cyclic voltammogram show that the deposition of $\mathrm{Fe}, \mathrm{Ni}$, and $\mathrm{W}$ alloy with $\mathrm{Cu}$ at $j=-450 \mathrm{~mA} \mathrm{~cm}^{-2}$ occurs at a potential which is about $0.2 \mathrm{~V}$ more negative than the deposition potential of the same alloy without $\mathrm{Cu}$ [35]. In the presence of $\mathrm{Cu}$, dendritic particles with a high density of secondary and higher-order branches are formed. The deposit has a considerably higher real surface area. This indicates that $\mathrm{Cu}^{2+}$ ions facilitate the formation of nuclei. Nucleus growth is determined by spherical diffusion, and this causes globule formation. Before reaching induction time for globules to develop into needle-like crystals, the formation of new nuclei takes place both on the tips and on the sides of the branches. This causes the formation of branches made up of globules. There are cracks between certain branches (Figure 1(a)). At the tips of sufficiently large particles made up of many 


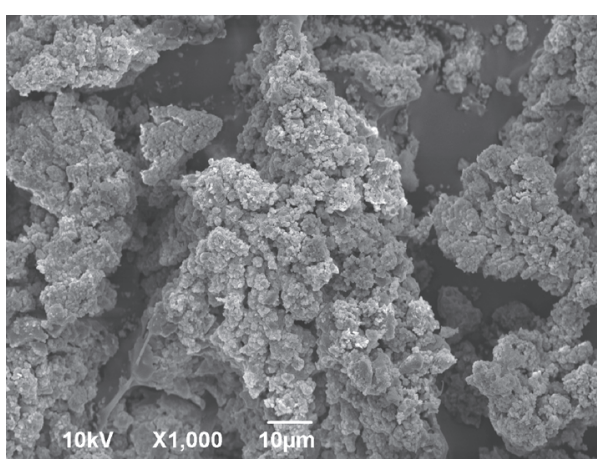

(a)

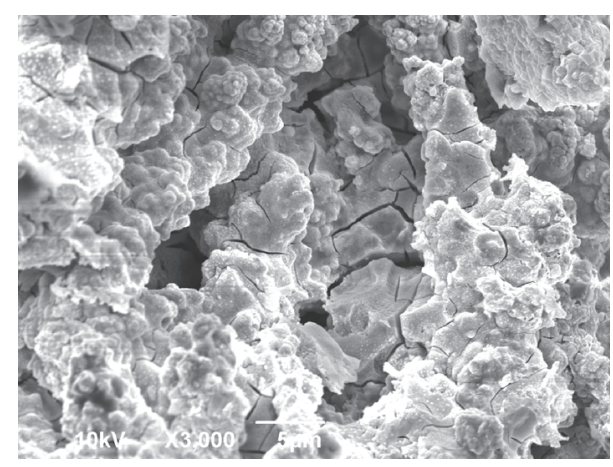

(b)

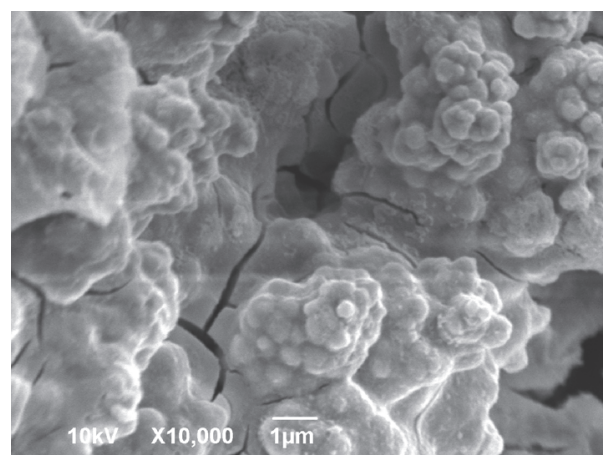

(c)

Figure 1: $\mathrm{SEM}$ micrographs of $\mathrm{Ni}_{85.8} \mathrm{Fe}_{10.6} \mathrm{~W}_{1.4} \mathrm{Cu}_{2.2}$ powders electrodeposited at $450 \mathrm{~mA} \mathrm{~cm}{ }^{-2}, t=60^{\circ} \mathrm{C}, \mathrm{pH}=9.2$.

branches, globules join to create a relatively rough external surface (Figures 1(b) and 1(c)). Then, the formation and growth of new globules occur on this surface (Figures 1(a) and $1(b))$. The figures also show a large number of cracks, indicating high internal microstrains of the deposit. The surface of the particles exhibits craters, that is, sites of hydrogen evolution occurring during the deposition.

The phase structure of $\mathrm{Ni}_{85.8} \mathrm{Fe}_{10.6} \mathrm{~W}_{1.4} \mathrm{Cu}_{2.2}$ alloy was determined by XRD analysis (Figure 2). XRD images of the electrodeposit show only the peaks of the FCC phase of the solid solution of iron, nickel, and copper in nickel for the crystal planes (111) and (200). No clearly defined peaks for the crystal phase of $\mathrm{WO}_{3}$ are observed. Likewise, there are no peaks for pure iron, tungsten, and pure copper phases, nor those for intermetallic compounds of iron, tungsten, copper, and nickel. The ratio of the relative integrated intensities of the (111) peak to that of the (200) peak of the as-produced $\mathrm{Ni}_{85.8} \mathrm{Fe}_{10.6} \mathrm{~W}_{1.4} \mathrm{Cu}_{2.2}$ alloy is the same as the ratio of the peaks of an untextured (randomly textured) nickel polycrystal. This indicates no texture existence, that is, no preferred growth along a particular orientation, and suggests that the strain is distributed in different directions as in the randomly textured nickel polycrystal.

The peaks of the FCC phase of the as-deposited $\mathrm{Ni}_{85.8} \mathrm{Fe}_{10.6} \mathrm{~W}_{1.4} \mathrm{Cu}_{2.2}$ alloy are relatively wide and of low intensity. Their maxima are shifted to lower $2 \theta$ values relative to the $2 \theta$ values of the maxima of the pure nickel FCC phase. Microstructural data for the crystalline FCC phase of the asdeposited powder are presented in Table 1(A).
As shown in Table 1(A), the crystalline grains exhibit a relatively small size, a high internal microstrain value, and a high minimum density of chaotically distributed dislocations. This microstructure is the result of the high electrodeposition current density applied as well as of the presence of iron, copper, and, particularly, tungsten in the FCC crystal lattice of the solid solution of nickel [7-17, 35].

The presence of tungsten, iron, and copper in the FCC solid solution of nickel inhibits crystalline grain growth [717]. Tungsten, iron, and copper cause an increase in the mean interatom distance in the FCC phase, resulting in the shift of peak maxima to lower $2 \theta$ values.

The as-deposited $\mathrm{Ni}_{85.8} \mathrm{Fe}_{10.6} \mathrm{~W}_{1.4} \mathrm{Cu}_{2.2}$ alloy powders were annealed for 60 minutes in an argon atmosphere at $300^{\circ} \mathrm{C}, 400^{\circ} \mathrm{C}, 500^{\circ} \mathrm{C}$, and $600^{\circ} \mathrm{C}$. Then, they were cooled at $25^{\circ} \mathrm{C}$ and their X-ray images were taken. The X-ray images of the powders annealed at $t \leq 400^{\circ} \mathrm{C}$ practically coincide with those of the as-deposited powders. This indicates that at temperatures below $400^{\circ} \mathrm{C}$ no crystallization of an amorphous phase possibly present in the sample and no FCC crystalline grain growth occur. The $\mathrm{X}$-ray images of the powders annealed at $500^{\circ} \mathrm{C}$ and $600^{\circ} \mathrm{C}$ show the existence of narrower and considerably higher intensity peaks of the FCC phase of the solid solution of tungsten, iron, and copper in nickel for the planes (111) and (200). This suggests that, in the temperature range of $500^{\circ} \mathrm{C}$ to $600^{\circ} \mathrm{C}$, amorphous phase crystallization and FCC crystalline grain growth take place, along with a decreasing internal microstrain value and a declining minimum density of chaotically distributed dislocations (Table 1(B)). 
TABLE 1: Microstructural data for the crystalline FCC phase of $\mathrm{Ni}_{85.8} \mathrm{Fe}_{10.6} \mathrm{~W}_{1.4} \mathrm{Cu}_{2.2}$ alloy: (A) as-deposited and (B) annealed for 60 minutes at $600^{\circ} \mathrm{C}$.

\begin{tabular}{|c|c|c|c|c|}
\hline & $\begin{array}{c}\text { Unit cell } \\
\text { parameters }(\mathrm{nm})\end{array}$ & $\begin{array}{l}\text { Mean crystallite } \\
\text { size value }(\mathrm{nm})\end{array}$ & $\begin{array}{l}\text { Mean microstrain } \\
\text { value }\end{array}$ & $\begin{array}{l}\text { Minimum density of } \\
\text { chaotically distributed } \\
\text { dislocations }\left(\mathrm{cm}^{-2}\right)\end{array}$ \\
\hline (A) & $a=0.35324(3)$ & $11.4(4)$ & $1.3(4) \cdot 10^{3}$ & $2.0(3) \cdot 10^{12}$ \\
\hline (B) & $a=0.35950$ & $24.1(2)$ & $0.3(2) \cdot 10^{3}$ & $0.08(3) \cdot 10^{12}$ \\
\hline
\end{tabular}

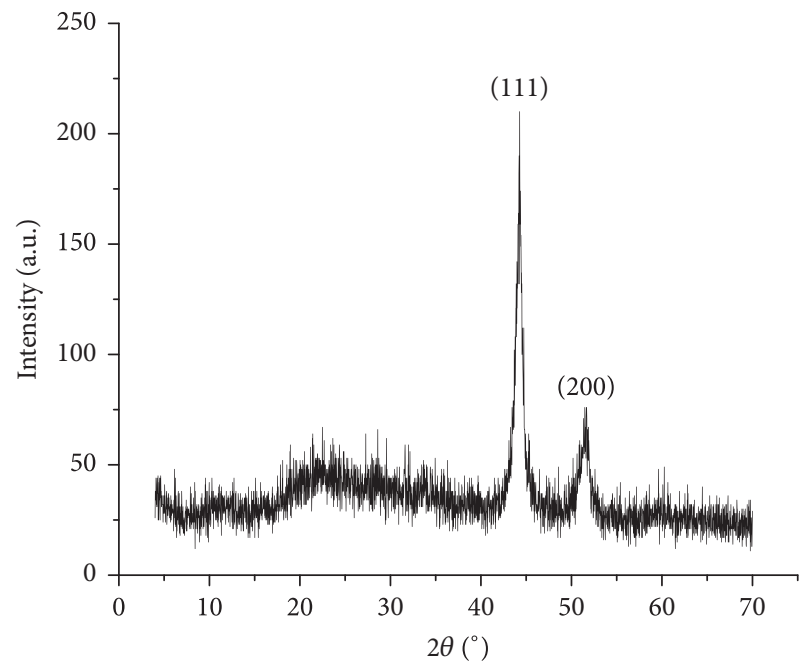

(a)

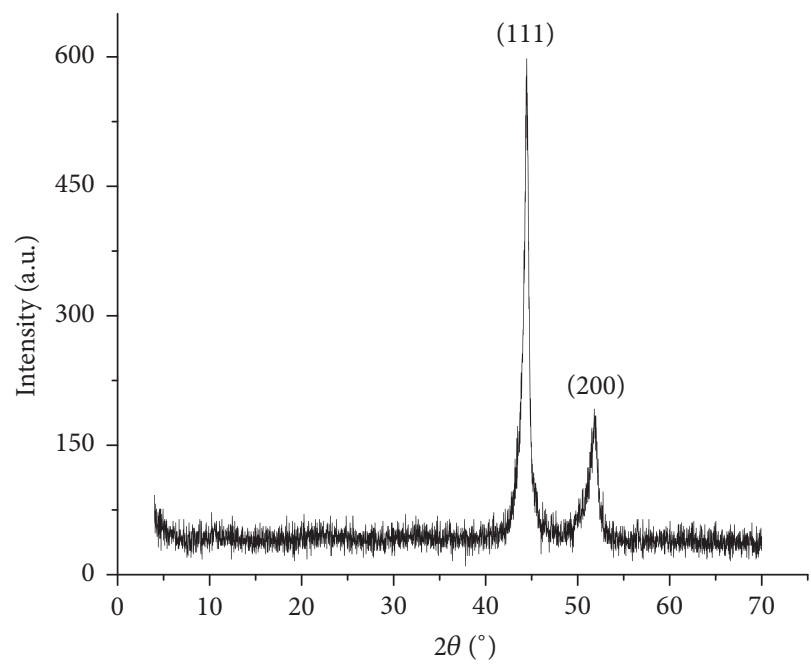

(b)

FIGURE 2: XRD images for (a) the as-deposited $\mathrm{Ni}_{85.8} \mathrm{Fe}_{10.6} \mathrm{~W}_{1.4} \mathrm{Cu}_{2.2}$ alloy and (b) the alloy annealed for 60 minutes at $600^{\circ} \mathrm{C}$.

The sum of the relative integrated intensities of the (111) and (200) peaks of the annealed samples is higher than the sum of the relative integrated intensities of the same peaks of the as-deposited samples. The ratio of the relative integrated intensities of the annealed sample to that of the asdeposited sample is $1: 0.67$. This indicates that about $33 \%$ of the amorphous phase is present in the deposit.

The effect of heat-induced structural changes on the electrical resistivity of the pressed $\mathrm{Ni}_{85.8} \mathrm{Fe}_{10.6} \mathrm{~W}_{1.4} \mathrm{Cu}_{2.3}$ alloy powder was also recorded. The as-produced pressed powder was heated from $25^{\circ} \mathrm{C}$ to $600^{\circ} \mathrm{C}$ at a rate of $20^{\circ} \mathrm{C} \mathrm{min}{ }^{-1}$. Upon reaching the maximum temperature $\left(600^{\circ} \mathrm{C}\right)$, the sample was cooled at $25^{\circ} \mathrm{C}$ and, then, reheated to $600^{\circ} \mathrm{C}$. During heating and cooling, changes in specific resistivity were monitored. The resulting temperature dependence of electrical resistivity is presented in Figure 3.

Figure 3 illustrates that electrical resistivity in the temperature range of $25^{\circ} \mathrm{C}-150^{\circ} \mathrm{C}$ increases linearly with increasing temperature. The temperature coefficient of electrical resistivity (TCER) in this range was $\alpha_{\mathrm{R}} 25^{\circ} \mathrm{C}-150^{\circ} \mathrm{C}=4.36$. $10^{-3} \mu \Omega \mathrm{m}^{\circ} \mathrm{C}^{-1}$. The resulting dependence presented in Figure 2 suggests no significant structural changes in the asdeposited sample during heating up to $150^{\circ} \mathrm{C}$.

The effect of structural changes during the annealing of $\mathrm{Ni}_{85.8} \mathrm{Fe}_{10.6} \mathrm{~W}_{1.4} \mathrm{Cu}_{2.3}$ alloy on electron density of states at the Fermi level was also examined. The electron density of states was determined from the temperature dependence of the thermoelectromotive force (TEMF) of

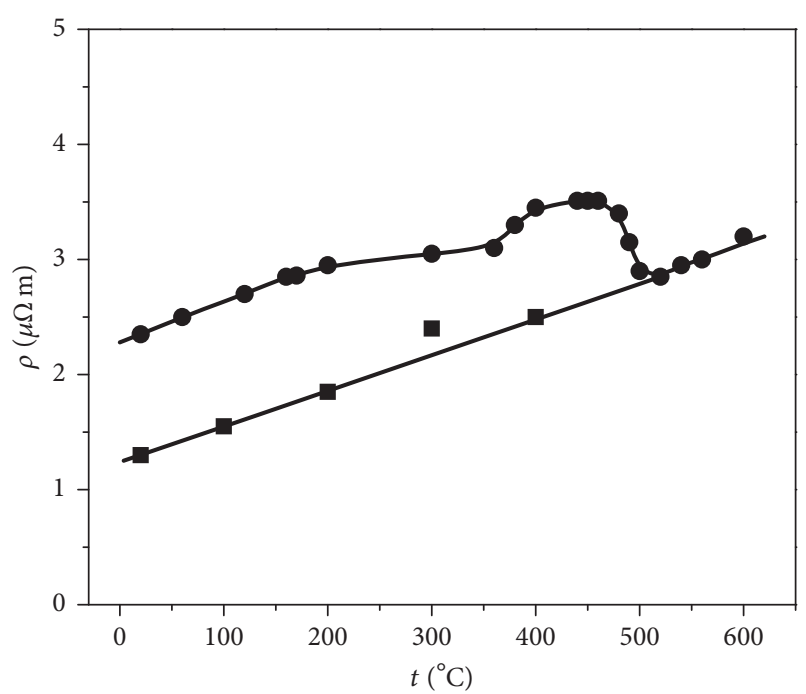

FIgURE 3: Temperature dependence of electrical resistivity: ๑: first heating; $\boldsymbol{\square}$ : first cooling and second heating. Heating and cooling rate: $20^{\circ} \mathrm{C} \mathrm{min}^{-1}$.

the copper-nanostructured alloy thermocouple. The alloy was annealed for 45 minutes at a defined temperature $\left(25^{\circ} \mathrm{C}\right.$, $150^{\circ} \mathrm{C}, 360^{\circ} \mathrm{C}, 420^{\circ} \mathrm{C}, 460^{\circ} \mathrm{C}, 520^{\circ} \mathrm{C}$, and $600^{\circ} \mathrm{C}$ ). Then, it was cooled at $25^{\circ} \mathrm{C}$ and reheated to the previous annealing temperature at a rate of $20^{\circ} \mathrm{C} \mathrm{min}{ }^{-1}$, with TEMF measurement simultaneously performed. 


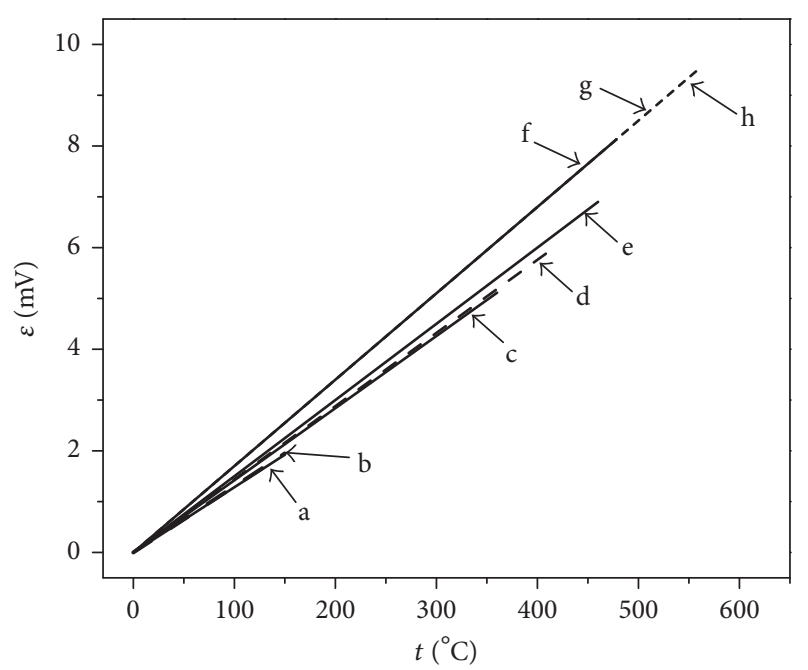

FIGURE 4: Temperature dependence of the TEMF of the thermocouple: $\mathrm{Cu}$-pressed $\mathrm{Ni}_{85.8} \mathrm{Fe}_{10.6} \mathrm{~W}_{1.4} \mathrm{Cu}_{2.3}$ alloy powder: (a) first heating of the nonannealed sample to $150^{\circ} \mathrm{C}$; (b) second heating of the preannealed sample to $150^{\circ} \mathrm{C}$ for 45 minutes at $150^{\circ} \mathrm{C}$; (c) third heating of the preannealed sample to $360^{\circ} \mathrm{C}$ for 45 minutes at $360^{\circ} \mathrm{C}$; (d) fourth heating of the preannealed sample to $420^{\circ} \mathrm{C}$ for 45 minutes at $420^{\circ} \mathrm{C}$; (e) fifth heating of the preannealed sample to $460^{\circ} \mathrm{C}$ for 45 minutes at $460^{\circ} \mathrm{C}$; (f) sixth heating of the preannealed sample to $520^{\circ} \mathrm{C}$ for 45 minutes at $520^{\circ} \mathrm{C}$; (g) seventh heating of the preannealed sample to $560^{\circ} \mathrm{C}$ for 45 minutes at $560^{\circ} \mathrm{C}$; and (h) eighth heating of the preannealed sample to $600^{\circ} \mathrm{C}$ for 45 minutes at $600^{\circ} \mathrm{C}$.

Figure 4 shows the dependences of the TEMF of the thermocouple on temperature: copper-pressed nanostructured $\mathrm{Ni}_{85.8} \mathrm{Fe}_{10.6} \mathrm{~W}_{1.4} \mathrm{Cu}_{2.3}$ alloy powder, annealed at different temperatures.

Figure 4 shows slight differences in TEMF values during the first and second heat treatments ( $a$ and b, resp.) to $150^{\circ} \mathrm{C}$. The slopes of the temperature dependence of TEMF have approximately the same values $\left(\alpha_{\mathrm{a}}=12.83 \mu \mathrm{V}^{\circ} \mathrm{C}^{-1}\right.$, $\left.\alpha_{\mathrm{b}}=13.0 \mu \mathrm{V}^{\circ} \mathrm{C}^{-1}\right)$. This also indicates that no significant structural changes occur in the alloy during annealing in the temperature range $25^{\circ} \mathrm{C}-150^{\circ} \mathrm{C}$.

The temperature dependence of electrical resistivity obtained during the first heating of the as-deposited powder presented in Figure 3 shows that electrical resistivity increases more slowly in the temperature range $150^{\circ} \mathrm{C}-360^{\circ} \mathrm{C}$ than in the range $25^{\circ} \mathrm{C}-150^{\circ} \mathrm{C}$. Therefore, the temperature coefficient of electrical resistivity in this range has a lower value $\alpha_{150^{\circ} \mathrm{C}-360^{\circ} \mathrm{C}}=1.6 \cdot 10^{-3} \mu \Omega \mathrm{m}^{\circ} \mathrm{C}^{-1}<\alpha_{25^{\circ} \mathrm{C}-150^{\circ} \mathrm{C}}=4.36$. $10^{-3} \mu \Omega \mathrm{m}^{\circ} \mathrm{C}^{-1}$.

The TEMF values obtained during the third heating of the sample to $360^{\circ} \mathrm{C}$ are higher than those during the second and first heat treatments (Figure 4 ). The temperature coefficient of TEMF was also considerably higher $\left(\alpha_{\mathrm{c}}=14.2 \mathrm{mV}^{\circ} \mathrm{C}^{-1}\right)$.

The temperature dependence of both TEMF and electrical resistivity suggests that intense structural relaxation takes place in the temperature range of $150^{\circ} \mathrm{C}-360^{\circ} \mathrm{C}$. During the structural relaxation, short-range ordering of the structure occurs simultaneously with decreasing internal microstrain and decreasing density of chaotically distributed dislocations.

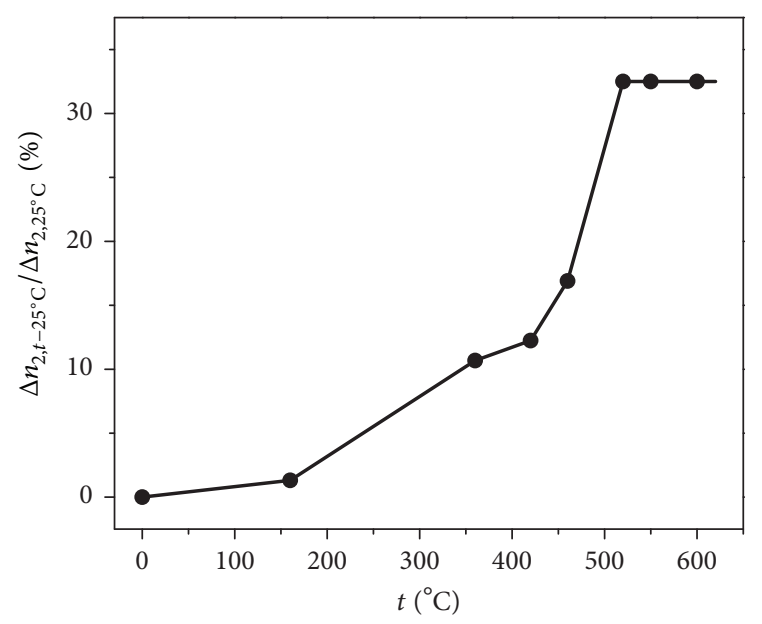

Figure 5: Relative changes in the electron density of states at the Fermi level as a function of annealing temperature for nanostructured $\mathrm{Ni}_{85.8} \mathrm{Fe}_{10.6} \mathrm{~W}_{1.4} \mathrm{Cu}_{2.3}$ alloy.

The heat applied in the temperature range of $150^{\circ} \mathrm{C}-360^{\circ} \mathrm{C}$ causes some atoms, mostly nickel and iron atoms having a higher potential energy, to cross over energy barriers and move into lower energy states. At these lower levels, their $3 \mathrm{~d}$ and $4 \mathrm{~s}$ orbitals better overlap with identical orbitals of neighboring atoms, thus increasing the electron density of states in the conduction band at the Fermi level. At the same time, this short-range ordering of the structure leads to an increase in the mean free path of electrons [9-11, 30, 34-36].

Relative changes in the electron density of states at the Fermi level during structural changes in an alloy can be determined using temperature dependence of TEMF. The temperature coefficients of TEMF are the function of the electron density of states at the Fermi level:

$$
\alpha=\frac{k}{2 e}\left(\frac{n_{1}}{n_{2}}-\frac{n_{2}}{n_{1}}\right),
$$

where $k$ is the Boltzmann constant, $e$ is electron charge, $n_{1}$ is electron density of states in copper, and $n_{2}$ is electron density of states in $\mathrm{Ni}_{85.8} \mathrm{Fe}_{10.6} \mathrm{~W}_{1.4} \mathrm{Cu}_{2.3}$ alloy. The electron density of states in copper remained practically unchanged during heating to $700^{\circ} \mathrm{C}$. Equation (1) was used to determine relative changes in the electron density of states in the alloy during its annealing at defined temperatures. The values obtained are presented in Figure 5.

Figure 5 shows that the relative change in the electron density of states in the annealed alloy at $150^{\circ} \mathrm{C}$ is

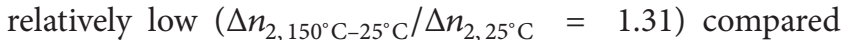
to the as-deposited sample. The low value of the change suggests that annealing the as-deposited nanostructured $\mathrm{Ni}_{85.8} \mathrm{Fe}_{10.6} \mathrm{~W}_{1.4} \mathrm{Cu}_{2.3}$ alloy sample at $150^{\circ} \mathrm{C}$ results in no significant structural changes in the alloy. In the temperature range between $25^{\circ} \mathrm{C}$ and $150^{\circ} \mathrm{C}$, the heat applied is insufficient to cause atoms from higher energy levels to move to lower energy (more stable) levels. Annealing the alloy at $360^{\circ} \mathrm{C}$ gives rise to significant changes in the electron density of states at the Fermi level in the alloy $\left(\Delta n_{2,360^{\circ} \mathrm{C}-25^{\circ} \mathrm{C}} / \Delta n_{2,25^{\circ} \mathrm{C}}=\right.$ $10.68 \%$ ) (Figure 5). This substantial change indicates that 
intense structural relaxation takes place in the alloy during annealing at $360^{\circ} \mathrm{C}$.

The intense structural relaxation and the increase in electron numbers in the conduction zone in the temperature range of $150^{\circ} \mathrm{C}$ to $360^{\circ} \mathrm{C}$ cause a decrease in the coefficient of electrical resistivity. It is likely that the dipole moment $\vec{p}$ becomes more uniformly oriented for certain nanoparticles in certain electronic states [34, 36-38].

The increased electron density of states $n_{2}$, the increased electron mean free path $\vec{l}$, and the more uniformly oriented dipole moment $\vec{p}$ cause a decrease in electrical resistivity and an increase in electrical conductivity in the structural relaxation temperature range according to the following relation:

$$
\sigma=\frac{n_{2} e^{2} \vec{l}}{\bar{v}},
$$

where $\bar{v}$ is the average velocity of electrons. Dipole moment is given by

$$
\vec{p}=\vec{l} \cdot e
$$

Combining (2) and (3) gives the following expression for electrical conductivity:

$$
\vec{\sigma}=\frac{n_{2} e^{2} \vec{p}}{\bar{v}} .
$$

The dipole moment has two contributions:

$$
\vec{p}=\overrightarrow{p_{\mathrm{el}}}+\overrightarrow{p_{\mathrm{ph}}}
$$

where $\overrightarrow{p_{\mathrm{el}}}$ is the dipole moment's electronic part, which is less dependent on temperature, and $\overrightarrow{p_{\mathrm{ph}}}$ is the phonon part, which is more sensitive to temperature as bosons are sensitive to anharmonic electron-phonon and electronmagnon interactions [34, 36-38].

Thus, temperature characteristics of electrical conductivity are influenced by phonon-electron interactions between the nano-confined electron states and the phonon subsystems, and in particular by anharmonic phonon-electron interactions.

In the temperature range between $360^{\circ} \mathrm{C}$ and $420^{\circ} \mathrm{C}$, electrical resistivity increases more rapidly with increasing temperature. This is the result of a negligible increase in the electron density of states at the Fermi level which was induced by slight structural relaxation in this temperature range.

Upon annealing at $420^{\circ} \mathrm{C}$, the relative change in the

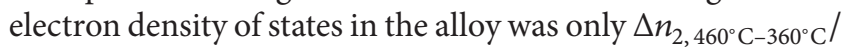
$\Delta n_{2,25^{\circ} \mathrm{C}}=1.56 \%$ compared to that in the alloy annealed at $360^{\circ} \mathrm{C}$. This suggests that structural relaxation in the alloy during heating from $360^{\circ} \mathrm{C}$ to $420^{\circ} \mathrm{C}$ is negligible.

In the temperature range of $420^{\circ} \mathrm{C}$ to $460^{\circ} \mathrm{C}$, electrical resistivity increases more slowly than in the previous range. The alloy annealed at $460^{\circ} \mathrm{C}$ exhibits an increase in the relative electron density of states at the Fermi level by $\Delta n_{2,460^{\circ} \mathrm{C}-420^{\circ} \mathrm{C}} / \Delta n_{2,25^{\circ} \mathrm{C}}=4.66 \%$ compared to the alloy annealed at $420^{\circ} \mathrm{C}$. This suggests reintensification of structural relaxation in the $420^{\circ} \mathrm{C}-460^{\circ} \mathrm{C}$ range. At temperatures above $420^{\circ} \mathrm{C}$, larger and less mobile tungsten atoms and copper atoms seem to receive enough heat to overcome the energy barriers and move from higher energy (less stable) levels to lower energy (more stable) levels. The stabilization of states of these atoms enables the stabilization of some of their neighboring nickel and iron atoms. At temperatures above $400^{\circ} \mathrm{C}$, in the temperature range between $400^{\circ} \mathrm{C}$ and $460^{\circ} \mathrm{C}$, heat causes magnetic domains to lose their orientation $[10,28,35,36]$. The reduction in magnetic domain arrangement leads to reduced interaction between conduction electrons and magnons, causing a decrease in the temperature coefficient of electrical resistivity.

The increase in temperature over the $460^{\circ} \mathrm{C}-520^{\circ} \mathrm{C}$ range causes a decrease in electrical resistivity (Figure 3 ). Annealing the $\mathrm{Ni}_{85.8} \mathrm{Fe}_{10.6} \mathrm{~W}_{1.4} \mathrm{Cu}_{2.2}$ alloy at $520^{\circ} \mathrm{C}$ gives rise to a considerable increase in the electron density of states at the Fermi level $\left(\Delta n_{2,520^{\circ} \mathrm{C}-460^{\circ} \mathrm{C}} / \Delta n_{2,25^{\circ} \mathrm{C}}=15.6 \%\right)$ (Figure 5). The high increase in the electron density of states and the abrupt decrease in electrical resistivity in this temperature range result from amorphous phase crystallization and crystal grain growth in the FCC-structured solid solution of iron, tungsten, and copper in nickel $[19,20,36]$. Crystallization was confirmed by X-ray diffraction (Figure 2 and Table 1).

Crystallization and crystal grain growth cause an increase in the mean free path of electrons in the conduction band and an increase in the electron density of states at the Fermi level, resulting in increased electrical conductivity of the alloy [17, 19, 20, 34, 36].

Annealing the alloy at $560^{\circ} \mathrm{C}$ and $600^{\circ} \mathrm{C}$ causes no significant changes in the electron density of states at the Fermi level (Figure 5). Electrical resistivity increases linearly with increasing temperature at temperatures above $520^{\circ} \mathrm{C}$ (Figure 4).

Upon heating to $600^{\circ} \mathrm{C}$, the sample was cooled at $25^{\circ}$ and reheated to $600^{\circ} \mathrm{C}$, while changes in electrical resistivity were simultaneously monitored. Figure 4 shows that resistivity linearly decreased as the temperature declined. During further heating, resistivity values were identical to those recorded during the cooling treatment (Figure 4). The changes in the electron density of states and electrical resistivity indicate no substantial structural changes in the temperature range $520^{\circ} \mathrm{C}-600^{\circ} \mathrm{C}$.

The experimental results and their analysis suggest that the temperature dependence of both TEMF and electrical resistivity can be used to determine temperature ranges for structural relaxation and crystallization. Moreover, correlations were found between structural changes, electron density of states at the Fermi level, and electrical resistivity.

\section{Conclusion}

Nanostructured $\mathrm{Ni}_{85.8} \mathrm{Fe}_{10.6} \mathrm{~W}_{1.4} \mathrm{Cu}_{2.2}$ alloy powder containing an amorphous matrix and FCC-phase crystals (with an average size of $11.4 \mathrm{~nm}$ ) of the solid solution of iron, tungsten, and copper in nickel was deposited from an ammonia citrate bath at a current density of $450 \mathrm{~mA} \mathrm{~cm}^{-2}$ on a titanium cathode. Heating the powder sample pressed at $500 \mathrm{MPa}$ in the temperature range of $25^{\circ} \mathrm{C}$ to $600^{\circ} \mathrm{C}$ induces 
structural changes in the alloy which cause changes in the electrical resistivity and thermoelectromotive force of the nanostructured $\mathrm{Ni}_{85.8} \mathrm{Fe}_{10.6} \mathrm{~W}_{1.4} \mathrm{Cu}_{2.2}$ alloy-copper thermocouple. When heated to $150^{\circ} \mathrm{C}$, the as-deposited powder undergoes no structural changes. In the temperature range $150^{\circ} \mathrm{C}-360^{\circ} \mathrm{C}$, intense structural relaxation occurs in the alloy involving short-range structural ordering and a decrease in both internal microstrain and density of chaotically distributed dislocations, leading to an increase in the mean free path of electrons in the conduction band as well as to an increase in the electron density of states at the Fermi level. It is likely that the dipole moment becomes more uniformly oriented for certain nanoparticles in certain electronic states. The increase in both the electron density of states and the mean free path of electrons and the more uniformly oriented dipole moment cause an increase in electrical conductivity. The intensity of structural relaxation was found to be negligible in the temperature range of $360^{\circ} \mathrm{C}-420^{\circ} \mathrm{C}$, and somewhat higher in the range $420^{\circ} \mathrm{C}-460^{\circ} \mathrm{C}$. The heat treatment at temperatures above $420^{\circ} \mathrm{C}$ gives rise to the stabilization of larger and less mobile tungsten atoms and copper atoms. The crystallization of the amorphous phase and FCC-phase crystal grain growth in the solid solution over the temperature range of $460^{\circ} \mathrm{C}-520^{\circ} \mathrm{C}$ cause a significant increase in electrical conductivity and the electron density of states at the Fermi level.

\section{Conflicts of Interest}

The authors declare that there are no conflicts of interest regarding the publication of this paper.

\section{Acknowledgments}

This study was financially supported by the Ministry of Education and Science of the Republic of Serbia through Project Ref. no. 172057.

\section{References}

[1] F. Hubenthal, Comprehensive Nanoscience and Technology, vol. 1.

[2] G. Panthi, M. Park, H. Y. Kim, S. J. Park, and J. Ind, "Electrospun polymeric nanofibers encapsulated with nanostructured materials and their applications: a review," Journal of Industrial and Engineering Chemistry, vol. 24, no. 1, 2015.

[3] M. A. Augustin and P. Sanguansri, "Nanostructured materials in the food industry," in Advances in Food and Nutrition Research, vol. 58, chapter 5, pp. 183-213, 2009.

[4] Z. Tang, C. He, H. Tian et al., "Polymeric nanostructured materials for biomedical applications," Progress in Polymer Science, vol. 60, pp. 86-128, 2015.

[5] L. X. Phua, N. N. Phuoc, and C. K. Ong, "Investigation of the microstructure, magnetic and microwave properties of electrodeposited $\mathrm{Ni}_{x} \mathrm{Fe}_{1-x}(\mathrm{x}=0.2-0.76)$ films," Journal of Alloys and Compounds, vol. 520, pp. 132-139, 2012.

[6] M. A. Oliver-Tolentino, E. M. Arce-Estrada, C. A. CortésEscobedo et al., "Electrochemical behavior of $\mathrm{Ni}_{x} \mathrm{~W}_{1-x}$ materials as catalyst for hydrogen evolution reaction in alkaline media," Journal of Alloys and Compounds, vol. 536, no. 1, pp. S245-S249, 2012.

[7] K. R. Sriraman, S. Ganesh Sundara Raman, and S. K. Seshadri, "Corrosion behaviour of electrodeposited nanocrystalline Ni$\mathrm{W}$ and Ni-Fe-W alloys," Materials Science and Engineering A, vol. 460-461, pp. 39-45, 2007.

[8] K. R. Sriraman, S. G. S. Raman, and S. K. Seshadri, "Synthesis and evaluation of hardness and sliding wear resistance of electrodeposited nanocrystalline $\mathrm{Ni}-\mathrm{Fe}-\mathrm{W}$ alloys," Materials Science and Technology, vol. 22, no. 14, pp. 14-22, 2006.

[9] L. Ribić-Zelenović, N. Ćirović, M. Spasojević, N. Mitrović, A. Maričić, and V. Pavlović, "Microstructural properties of electrochemically prepared Ni-Fe-W powders," Materials Chemistry and Physics, vol. 135, no. 1, pp. 212-219, 2012.

[10] M. Spasojević, L. Ribić-Zelenović, A. Maričić, and P. Spasojević, "Structure and magnetic properties of electrodeposited Ni87.3Fell.3W1.4 alloy," Powder Technology, vol. 254, pp. 439447, 2014.

[11] M. Spasojević, N. Ćirović, L. Ribić-Zelenović, P. Spasojevic, and A. Maričić, "Effect of deposition current density and annealing temperature on the microstructure, hardness and magnetic properties of nanostructured nickel-iron-tungsten alloys," Journal of the Electrochemical Society, vol. 161, p. D463, 2014.

[12] P. Esther, C. Joseph Kennady, P. Saravanan, and T. Venkatachalam, "Structural and magnetic properties of electrodeposited $\mathrm{Ni}-\mathrm{Fe}-\mathrm{W}$ thin films," Journal of Non-Oxide Glasses, vol. 1, article 301, 2009.

[13] F. He, J. Yang, T. Lei, and C. Gu, "Structure and properties of electrodeposited $\mathrm{Fe}-\mathrm{Ni}-\mathrm{W}$ alloys with different levels of tungsten content: a comparative study," Applied Surface Science, vol. 253, p. 7591, 2007.

[14] M. Donten, H. Cesiulis, and Z. Stojek, "Electrodeposition and properties of $\mathrm{Ni}-\mathrm{W}, \mathrm{Fe}-\mathrm{W}$ and $\mathrm{Fe}-\mathrm{Ni}-\mathrm{W}$ amorphous alloys. A comparative study," Electrochimica Acta, vol. 45, no. 20, pp. 3389-3396, 2000.

[15] S.-J. Mun, M. Kim, T.-H. Yim, J.-H. Lee, and T. Kang, "Mechanical and structural characteristics of electrodeposited Ni-FeW alloy after heat-treatment," Journal of the Electrochemical Society, vol. 157, no. 3, pp. D177-D180, 2010.

[16] N. Ćirović, P. Spasojević, L. Ribić-Zelenović, P. Mašković, and M. Spasojević, "Synthesis, structure and properties of nickeliron-tungsten alloy electrodeposits part I: effect of synthesis parameters on chemical composition, microstructure and morphology," Science of Sintering, vol. 47, no. 3, pp. 347-365, 2015.

[17] M. Banerjee, A. Singh, A. K. Majumdar, and A. K. Nigam, "Signature effects of spin clustering and distribution of spin couplings on magnetization behaviour in $\mathrm{Ni}-\mathrm{Fe}-\mathrm{Mo}$ and $\mathrm{Ni}-\mathrm{Fe}-\mathrm{W}$ alloys," Journal of Physics: Condensed Matter, vol. 23, Article ID 306004, 2011.

[18] T. Dastagir, W. Xu, S. Sinha, H. Wu, Y. Cao, and H. Yu, “Tuning the permeability of permalloy films for on-chip inductor applications," Applied Physics Letters, vol. 97, Article ID 162506, 2010.

[19] E. Kubo, N. Ooi, H. Aoki et al., "Effect of magnetic field on permeability of electroplated permalloy for microdevices," Japanese Journal of Applied Physics, vol. 49, Article ID 04DB17$1,2010$.

[20] T. O’Donnell, N. Wang, S. Kulkarni et al., "Electrodeposited anisotropic NiFe 45/55 thin films for high-frequency microinductor applications," Journal of Magnetism and Magnetic Materials, vol. 322, no. 9-12, pp. 1690-1693, 2010. 
[21] O. Song, C. A. Ballentine, and R. C. O’Handley, "Giant surface magnetostriction in polycrystalline $\mathrm{Ni}$ and NiFe films," Applied Physics Letters, vol. 64, no. 19, pp. 2593-2595, 1994.

[22] C. Jiang, D. Xue, and W. Sui, "Broadband microwave absorption in $[\mathrm{NiFe} / \mathrm{FeMn}] \mathrm{n}$ exchange-coupled multilayer films," Thin Solid Films, vol. 519, no. 8, pp. 2527-2530, 2011.

[23] B. Koo and B. Yoo, "Electrodeposition of low-stress NiFe thin films from a highly acidic electrolyte," Surface and Coatings Technology, vol. 205, p. 740, 2010.

[24] B. K. Kuanr, R. Marson, S. R. Mishra, A. V. Kuanr, R. E. Camley, and Z. J. Celinski, "Gigahertz frequency tunable noise suppressor using nickel nanorod arrays and Permalloy films," Journal of Applied Physics, vol. 105, no. 7, Article ID 07A520, 2009.

[25] S. H. Hong and H. J. Ryu, "Combination of mechanical alloying and two-stage sintering of a $93 \mathrm{~W}-5.6 \mathrm{Ni}-1.4 \mathrm{Fe}$ tungsten heavy alloy," Materials Science and Engineering: A, vol. 344, p. 253, 2003.

[26] Z. W. Zhang, J. E. Zhou, S. Q. Xi, G. Ran, P. L. Li, and W. X. Zhang, "Formation of crystalline and amorphous solid solutions of W-Ni-Fe powder during mechanical alloying," Journal of Alloys and Compounds, vol. 370, p. 186, 2004.

[27] Z. W. Zhang, J. E. Zhou, S. Q. Xi, G. Ran, and P. L. Li, "Phase transformation and thermal stability of mechanically alloyed W-Ni-Fe composite materials," Materials Science and Engineering: A, vol. 379, p. 148, 2004.

[28] N. Ćirović, P. Spasojević, L. Ribić-Zelenović, P. Mašković, A. Maričič, and M. Spasojević, "Synthesis, structure and properties of nickel-iron-tungsten alloy electrodeposits: part II: effect of microstructure on hardness, electrical and magnetic properties," Science of Sintering, vol. 48, no. 1, pp. 1-16, 2016.

[29] K. I. Popov and M. G. Pavlović, "Electrodeposition of metal powders with controlled particle grain size and morphology," in Modern Aspects of Electrochemistry, B. E. Conway, J. O. M. Bockris, and R. E. White, Eds., Plenum, NY, USA, 1973, 24.

[30] L. Ribić-Zelenović, M. Spasojević, N. Ćirović, P. Spasojević, and A. Maričić, "Effect of milling and annealing on microstructural, electrical and magnetic properties of electrodeposited Ni11.3Fe-1.4W alloy," Science of Sintering, vol. 44, no. 2, pp. 197-210, 2012.

[31] F. Barariu and H. Chiriac, "Thermoelectromotive force in nanocrystalline wires," Nanostructured Materials, vol. 12, no. 5, pp. 967-970, 1999.

[32] H. Chiriac, F. Barariu, and V. Nagacevschi, "Thermoelectromotive force in magnetic amorphous-crystalline Fe79Si5B16 wire systems," Journal of Magnetism and Magnetic Materials, vol. 160, pp. 239-240, 1996.

[33] H. Chiriac, A. Inoue, F. Barariu, and V. Nagacevschi, "Thermoelectromotive force of amorphous magnetic $\mathrm{Fe}-\mathrm{Cu}-\mathrm{Nb}-\mathrm{Si}$ $\mathrm{B}, \mathrm{Fe}-\mathrm{Hf}-\mathrm{B}$ and Fe-Zr-B ribbons during the crystallization process," Materials Science and Engineering: A, vol. 226-228, pp. 650-653, 1997.

[34] L. Ribić-Zelenović, L. Rafailović, M. Spasojević, and A. Maričić, "Correlation between electron state density change and the electrical resistivity and magnetic permeability changes in the nanostructured powder of the NiMo alloy," Physica B: Condensed Matter, vol. 403, no. 12, pp. 2148-2154, 2008.

[35] M. Spasojevic and D. Gospavic, "Microstructure and magnetic properties of electrodeposited Ni85.8Fe10.6W1.4Cu2.2 alloy powder," Journal of The Electrochemical Society, vol. 163, p. D842, 2016.
[36] Z. Vuković, P. Spasojević, M. Plazinić, J. Živanić, and M. Spasojević, "The effect of annealing temperatures on magnetic and electric properties of electrodeposited Ni85,3Fe10,6W1,4Cu2,2 alloy," Journal of Optoelectronics and Advanced Materials, vol. 16, p. 985, 2014.

[37] K. Nouneh, I. V. Kityk, R. Viennois et al., "Non-linear optical effects and transport phenomena of magnetic semiconductors Pb1-xPrxTe near the semiconductor-metal phase transformation," Journal of Physics D: Applied Physics, vol. 38, no. 7, pp. 965-973, 2005.

[38] M. Donten, Z. Stojek, and H. Cesiulis, "Formation of nanofibers in thin layers of amorphous $\mathrm{W}$ alloys with $\mathrm{Ni}, \mathrm{Co}$, and $\mathrm{Fe}$ obtained by electrodeposition," Journal of the Electrochemical Society, vol. 150, no. 2, pp. C95-C98, 2003. 

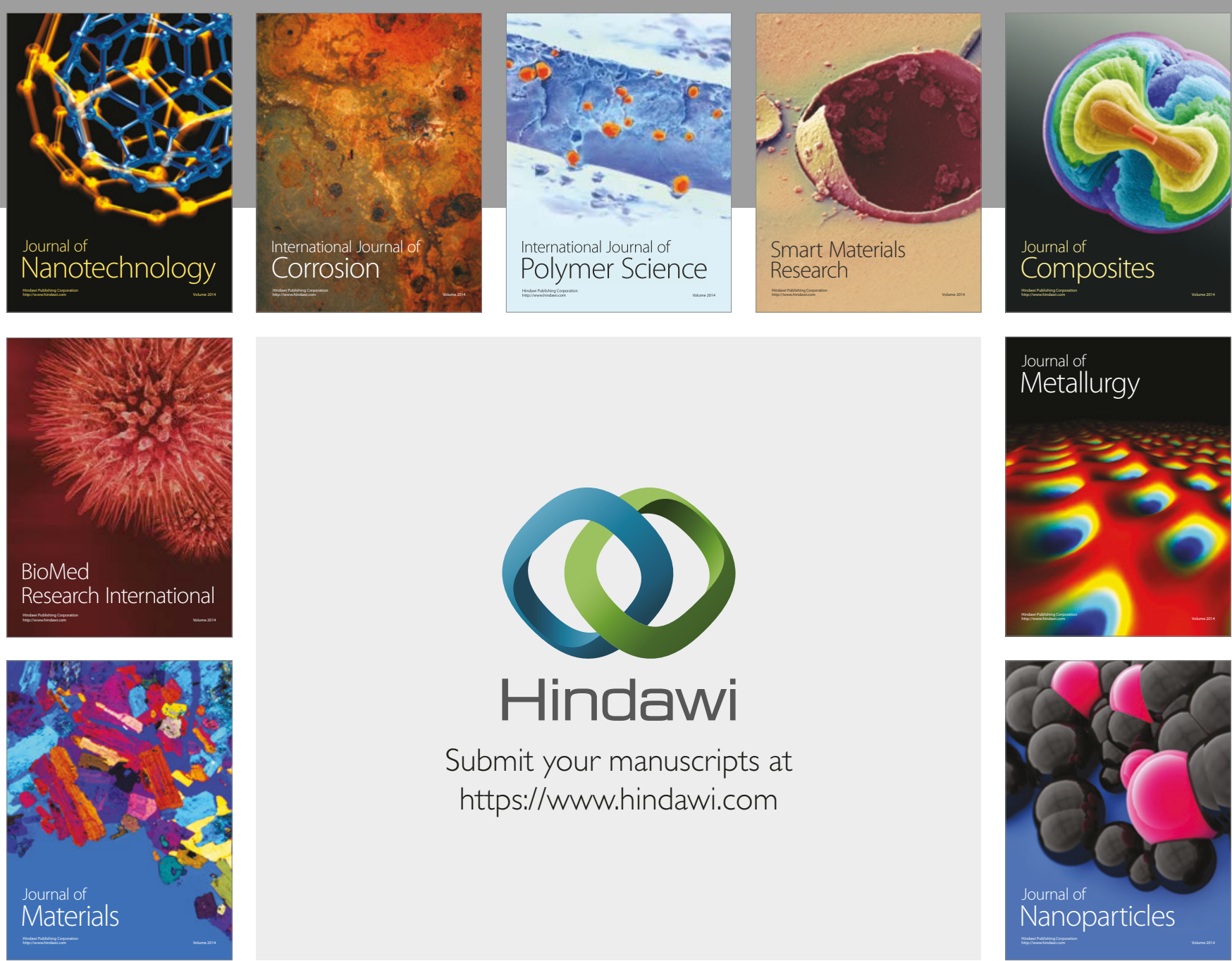

\section{Hindawi}

Submit your manuscripts at

https://www.hindawi.com
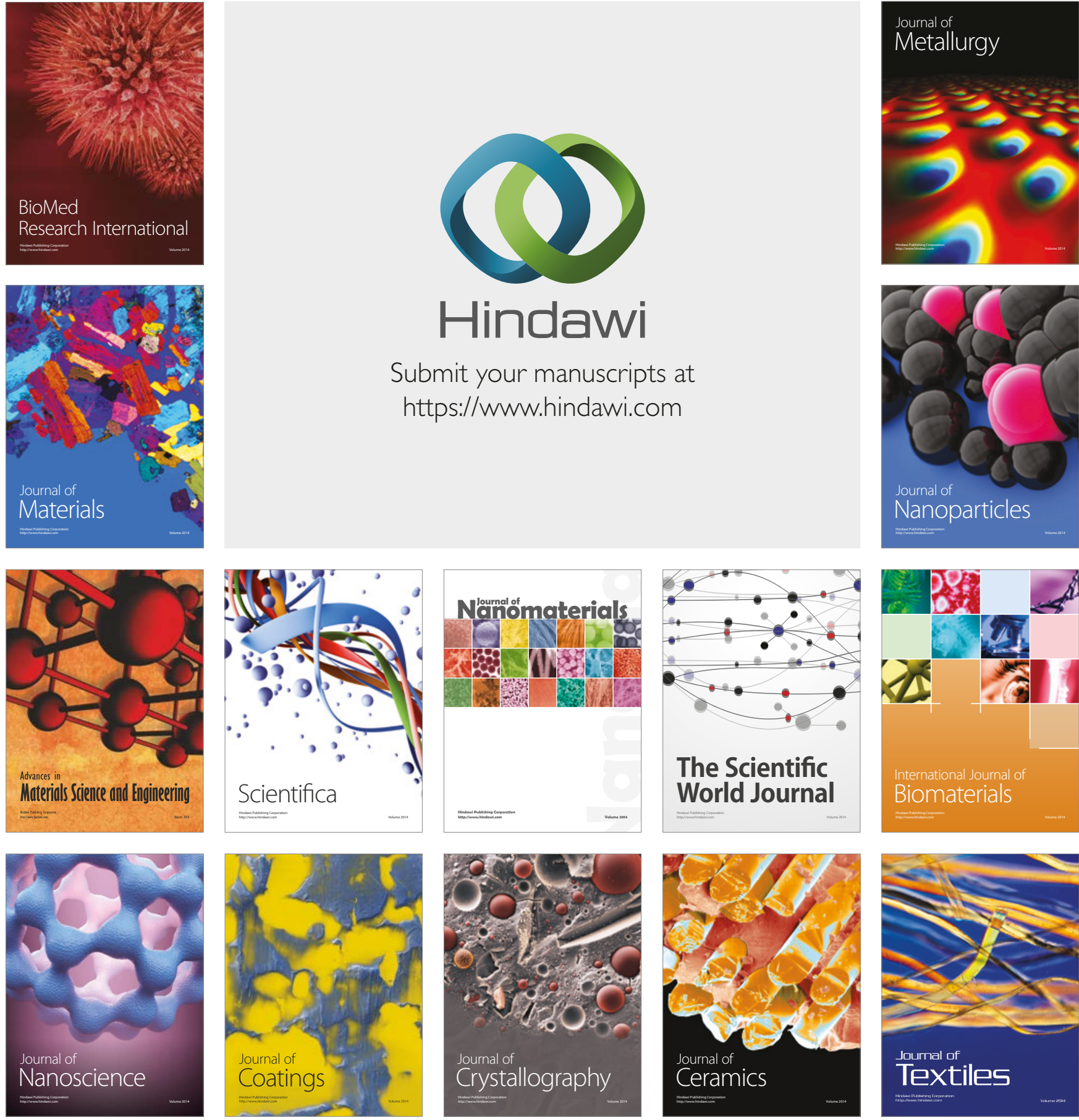

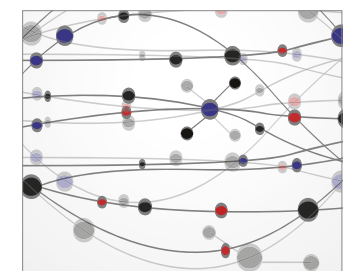

The Scientific World Journal
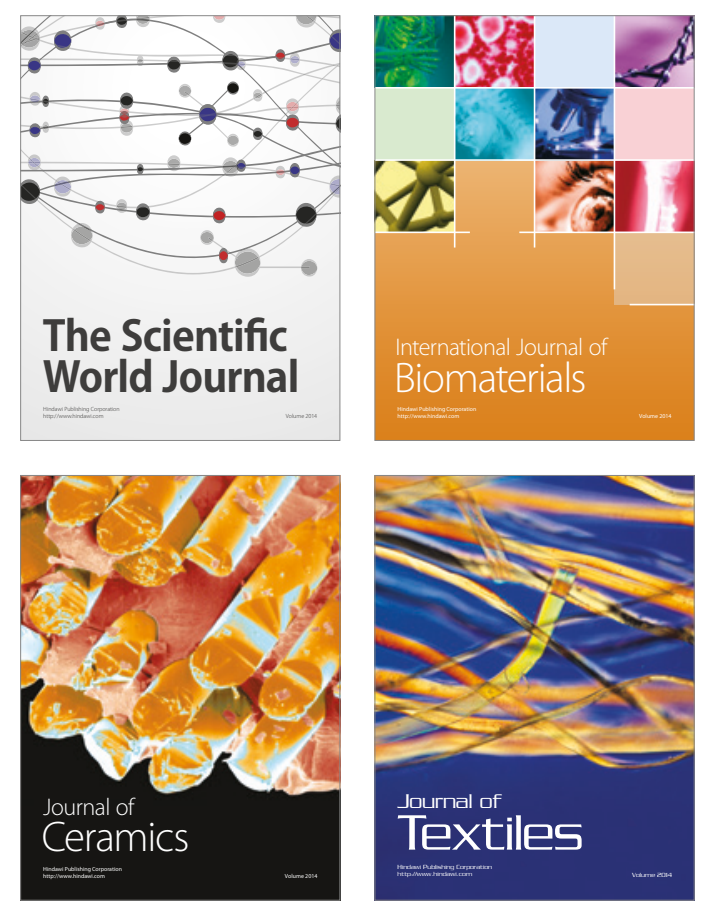